\author{
О.С. Назаров ${ }^{1}$, В.Ф. Ганкевич ${ }^{2}$, О.А. Пащенко ${ }^{2}$, В.Я. Кіба ${ }^{2}$ \\ ${ }^{1}$ Інститут геотехнічної механіки НАН України \\ ${ }^{2}$ Національний технічний університет «Дніпровська політехніка»
}

\title{
ШЛЯХИ ЗМЕНШЕННЯ ЕНЕРГОСМНОСТІ І ПІДВИЩЕННЯ ПРОДУКТИВНОСТІ ПРИ БУРІННІ СВЕРДЛОВИН
}

\begin{abstract}
В роботі розглянуто напрями та розробки що направлені на підвищення продуктивності процесу буріння, зниження енерговитрат і підвищення надійності обладнання, в першу чергу інструменту. Так розглянуто застосування гідравлічних бурових установок, що дозволяють: знизити в 1,5...1,8 рази масу бурової установки, скоротити в 1,5 рази час спускопідімальні операції; забезпечити підвищення швидкості буріння в $1,3 \ldots 2$ рази, знизити час на нарощування бурильних труб в 2,5 рази, скоротити час на монтаж і демонтаж установки в $2 . . .5$ разів. Дослідження процесу руйнування гірської породи показали, що вплив ПАР на гірську породу викликає ії разупрочнення і покращує умови іiі руйнування. Застосування добавок ДБ збільшує швидкість обертального буріння на 25 - 30 \% і глибину проходки до його затуплення на 20 - 25 \%. Результати дослідно-промислових випробувань показали, що використання добавок піноутворювача ДБ в промивної рідини при обертальному бурінні економічно доцільно. Роботи по розробці теоретичних моделей руйнування [8] шляхом математичного моделювання дозволяють розрахувати нелінійні безрозмірні залежності; частот і амплітуд поперечних власних коливань бурового ставу як від параметрів обертання ставу, так і від зовнішніх факторів. Спираючись на теорію подібності та аналізу розмірностей це дозволяє вивчити вплив параметрів не окремо, а в комплексі, що зменшує обсяг досліджень до 2-х раз. Також розробляються системи гасіння поперечних коливань НСП, ефективність, якої перевіряється розрахунками і моделюється за допомогою SolidWorks, що виключає флатер бурового інструменту. Проводяться розробки моделей верстатів шарошкового буріння, які дозволяють виробнику верстатів вибирати раціональні параметри систем гасіння поперечних коливань бурових ставів, проект верстата використаний для розробки робочої документації діючої моделі. Наукове і інженерне забезпечення виконується Національним технічним університетом «Дніпровська політехніка», Інститутом геотехнічної механіки та іншими організаціями.
\end{abstract}

DOI: $10.34185 / 0543-5749.2020-2-10-19$

\section{Вступ}

Двадцяте століття - століття інтенсивного розвитку фізики і техніки: телебачення, авіація (реактивні, надзвукові літаки), розділ атомного ядра (атомні електростанції і зброя), лазер (зварювання, порізка металу), комп'ютерні технології, медицина, інтернет.

Завдяки розвитку інтернет-технологій стала доступною інформація про досягнення в різних областях знань i зокрема техніки i технології видобутку, а також переробки корисних копалин.

Значна частка енерговитрат при видобутку та переробки корисних копалин витрачається на буровибухові роботи.
Більшість досліджень в області буріння i руйнування порід як вітчизняними вченими, та також мета даної роботи є розробки направлені на підвищення продуктивності процесу зниження енерговитрат і підвищення надійності обладнання, в першу чергу інструменту.

Зниженню енергоємності процесу буріння свердловин присвячені роботи [1 - 3].

Підвищенню терміну служби ріжучого інструменту присвячена робота [4] за допомогою обробки ріжучої частини твердосплавних пластинки лазером; за допомогою нової конструкції породоруйнівного інструменту [9] досягається підвищення його надійності і продуктивності при бурінні свердловин по міцним гірських по-

(C) Назаров О.Є., Ганкевич В.Ф., Пащенко О.А., Кіба В.Я., 2020 
рід, для цієї ж мети рекомендовані свердловинні амортизатори [10]; для запобігання флатера при бурінні підвищення техніки безпеки і комфортності робіт проведені дослідження [11].

Сучасні бурові установки, які відповідають передовим досягненням науки і техніки, мають високі техніко-економічними показниками та здатні бурити свердловини глибиною до 8000 метрів. Так гідравлічні бурові установки мають високий рівень механізації і автоматизації виробничих процесів. Використання рухомого обертача знижує витрати часу на допоміжні процеси в $1,3 . .2$ рази; плавне регулювання обертання i руху бурового снаряда при бурінні i спускопідіймальних операціях знижує витрати часу в $1,2 \ldots 1,5$ рази, підвищує механічну і рейсову швидкості буріння в $1,5 \ldots 2,5$ рази, знижає витрати бурових доліт в $1,2 \ldots 1,3$ рази і за рахунок цього вартість спорудження глибоких свердловин знижується на 20...50\% \% [10].

Бурові установки виконуються в самохідному виконанні і забезпечуються сучасними транспортними засобами, що призводить до зниження витрат часу на монтажно-демонтажні роботи в $2 . .5$ разів.

Головні переваги гідравлічних бурових установок:

- заміна талевої системи гідравлічним підйомником спрощує конструкцію установки, знижує в $1,5 \ldots 1,8$ рази загальну масу і скорочує в 1,5 рази час спускопідімальних операцій;

- застосування рухомого обертача забезпечує підвищення швидкості буріння в $1,3 . . .2$ рази, зниження часу на нарощування бурильних труб в 2,5 рази;

- застосування великоблочних модулів і спеціальних транспортних засобів скорочує час на монтаж і демонтаж установки в 2...5 разів.

Використання прогресивної технології буріння, забезпечується рухомим гідравлічним обертачем, знижаючи витрати часу на спорудження свердловини на $20 \ldots 25 \%$. Економічний ефект від використання гідравлічної бурової установки замість стандартної установки 3 талевої системою складає близько $\$ 2 . .2,5$ млн.

\section{Методика}

Дослідженнями щодо зниження енергоємності при руйнуванні гірської породи [2] було встановлено, що ущільнене ядро утворюється при клиноподібної формі передній грані різця, що має кут до $60^{\circ}$ при глибині зрізу менше 3 мм. Велику роль в утворенні ядра ущільнення має товщина стружки. Наприклад, при різанні породи 3 нульовим переднім кутом не спостерігається утворення ядра ущільнення при глибині зрізу менше 2 мм. Збільшення товщини стружки сприяє утворенню переізмільченої маси в предрізцовому просторі.

Істотний вплив на ядро ущільнення надає кут різання. Так, при вуглі різання більше $90^{\circ} \mathrm{i}$ при незначних товщинах зрізу ядро утворюється і орієнтується вглиб масиву ускладнюючи умови відколу [1].

Наприклад, дослідження процесу різання показали, що при малих кутах різання порода руйнувалася, так типово тендітне тіло, а при куті різання $90^{\circ}$ відбувалося зминання і дроблення, подрібнена маса вичавлювалася в напрямку вільної поверхні. Руйнування солі 3 утворенням ядра ущільнення характеризувалося i утворенням тріщин, що мали кут $45^{\circ}$ відносно площини руху різця. На ядро ущільнення впливає також форма ріжучої кромки. Так при малих кутах нахилу бічних крайок відбувається затиск породи вже при незначній глибині різання [1].

Слід очікувати і істотний вплив форми передньої грані на створення ядра ущільнення. Форма передньої грані овальна або клиноподібна повинна викликати менший затиск і переруйнування породи в передрізцовій зоні, ніж плоска.

Поряд з геометричними факторами освіти i видалення ядра ущільнення необхідно враховувати і роль тертя гірської породи по інструменту, яке істотно впливає в процесі різання.

В ІГТМ НАН України були проведені експериментальні дослідження по утворенню і видаленню ядра ущільнення з передрізцової зони. Різання здійснювалося на спеціальному стенді, що дозволяє, виробляти елементарний скол породи з виміром зусилля різання трикомпонентним динамометром, сигнал від якого подавався на осцилограф Н-700.

При різанні вуглецементного блоку 3 товщиною стружки 10 мм без змазування передній грані різця прикладені сили для кутів різання $60^{\circ}$ і $90^{\circ}$ склали відповідно 1350 і 2380 Н. При зменшенні коефіцієнта тертя на границі різецьпорода за допомогою мінерального масла зусилля різання відповідно склали 810 i $1620 \mathrm{H}$, що значно менше, ніж при сухому руйнуванні [2].

Аналогічне явище спостерігається при дослідженні гірських порід при змащуванні торців породи. Там де торці змащені, руйнування гірських порід відбувається без помітного освіти ядра ущільнення переважно за рахунок напруг, що розтягують. У цьому випадку зазначалося, 
що різання зі змащеною передньою гранню не викликало зминання гірської породи на площині відколу. Це свідчить про збільшення частки напруг, що розтягують в загальній картині навантаження. При сухому різанні чітко спостерігалися сліди зім'ятої породи, що говорить про істотну роль стискаючих напруг i наявності ядра ущільнення.

Проведені експерименти показали, що на процес різання, 3 точки зору ядра ущільнення, впливають кут різання і сила тертя на кордоні різець-порода.

За результатами експериментальних досліджень встановлено, що при зростанні кута різання більше $70^{\circ}$, зусилля яке йде на скол елемента стружки різко зростає, що пояснюється збільшенням затиску породи в передрізцовій зоні.

Проведені дослідження по утворенню і видаленню ядра ущільнення при різанні гірських порід дозволили встановити, що на його створення впливають як кут різання, так і коефіцієнт тертя на границі різець-порода.

При бурінні в гірських породах 3 промиванням, подача води в предрізцову зону утруднена через малий зазор між різцем і породою. Проникнення води стримується досить великою величиною іiі поверхневого натягу. Тому, щоб подати промивну рідину в зоні руйнування, необхідно збільшити плинність води шляхом добавки в неї поверхнево-активних речовин (ПАР). Добавки ПАР в воду крім зменшення в'язкості розчину знижують і коефіцієнт тертя, що дуже важливо при різанні порід.

Проведені дослідження зміни коефіцієнтів тертя між різцем і породою 3 додаванням у воду ПАР (сульфаіола «Прогрес») дозволили встановити, що величина коефіцієнта тертя зменшується в $3-6$ разів, при цьому значення поверхневого натягу зменшується в $2-3$ рази. Добавки ПАР в промивну рідину, крім вище сказаного, мають ще властивістю зниження поверхневої енергії руйнується породи (ефект Ребендера) [3].

Експериментальне буріння із застосуванням ПАР (сульфанола і "Прогресу") для виносу продуктів руйнування показало, що швидкість обертального буріння зростає в $1,4-1,8$ рази. Швидкість буріння збільшується внаслідок зниження поверхневої енергії руйнується породи і зменшення коефіцієнта тертя на кордоні різець-порода.

Виходячи 3 викладеного, можна сказати, що додавання поверхневоактивних речовин в промивну рідину зменшує величину ядра ущільнення, покращує умови охолодження твердого сплаву, а також знижує міцнісні властивості гірської породи на вибої свердловини за рахунок адсорбційних ефекту.

При вивченні процесу руйнування гірських порід різанням, встановлено, що доцільно зменшувати сили тертя між породою і твердим сплавом. Зменшення сил тертя можливо шляхом подачі рідини в зону перед резцом або шляхом зменшення жорсткості твердого сплаву. Необхідно відзначити, що подача рідини в зону руйнування покращує умови охолодження твердого сплаву, який в процесі різання (в зоні контакту з породою) може нагріватися до температури $600-800{ }^{\circ} \mathrm{C}$. Тому рідина, яка подається в зону руйнування, повинна забезпечувати зменшення сил тертя н знижувати коефіцієнт поверхневого натягу, що підвищить іiі проникаючу здатність.

Для дослідження міцнісних властивостей гірських порід були застосовані добавки поверхнево-активних речовин (ПАР), серед яких найбільш поширений змочувач ДБ, що є неіоногенним ПАР, синтезованим 3 алефінов фенолу i окису етилену.

Перетворювач ДБ добре розчиняється у воді будь-якої жорсткості при будь-якій температурі, утворюючи колоїдні розчини.

Дослідженнями науково-дослідного інституту гігієни праці та профзахворювань встановлено, що змочувач не має токсичних властивостей. Пенообразуюча здатність досить низька, тому для зменшення піноутворення використовують додаткові добавки гидролизованого поліакріламіду.

Поверхневий натяг різних розчинів ДБ, визначений методом найбільшого тиску бульбашок, засновано на тому, що тиск, необхідний для відриву бульбашок повітря від капіляра, зануреного в рідину, прямо пропорційний поверхневому натягу. Результати визначення поверхневого натягу наступні:

Таблиця 1. Залежність поверхневого натягу від концентрації ДБ

\begin{tabular}{|c|c|c|c|c|c|c|c|c|c|}
\hline Концентрації ДБ,\% & 0 & 0,005 & 0,01 & 0,02 & 0,05 & 0,1 & 0,2 & 0,5 & 1 \\
\hline Поверхневий натяг & 72,75 & 65,52 & 57,52 & 43,64 & 33,75 & 29,53 & 28,95 & 28,8 & 29,9 \\
\hline
\end{tabular}


Отже, добавки в воду ДБ порядка 0,051 більш ніж в 2 рази знижують поверхневий натяг, що сприяє проникненню промивної рідини в зону руйнування.

Таким чином встановлено, що введення ПАР в промивну рідину або полірування твердого сплаву знижує коефіцієнт тертя, твердий «сплав-порода», що, в свою чергу, покращує умови руйнування.

3 метою дослідження впливу полірування твердого сплаву і промивних рідин на властивості міцності гірських порід були проведені екс- перименти по визначенню межі міцності на стиск граніту і пісковику в сухому стані, занурених у воду і в воду з добавкою $0,05 \%$ змочувача ДБ. Ці дослідження межі міцності проводилися 3 використанням твердосплавних пуансонів 3 поверхнями, обробленими заточним колом (з шорсткою поверхнею) і відполірованими алмазними порошками до дзеркального блиску. В результаті експериментальних досліджень встановлено, що міцність гірських порід в рідини зменшується, однак у граніту це більш яскраво виражено, ніж у пісковика (табл. 2).

Таблиця 2. Показники границі міцності

\begin{tabular}{|c|c|c|}
\hline \multirow{2}{*}{ Середовище } & \multicolumn{2}{|c|}{ Межа міцності, $\mathrm{H} / \mathrm{cm}^{2}$} \\
\cline { 2 - 3 } & Граніт & Піщаник \\
\hline Повітря & $164 / 153$ & $262 / 258$ \\
\hline Вода & $134 / 122$ & $256 / 251$ \\
\hline Вода + ДБ & $97 / 87$ & $237 / 240$ \\
\hline
\end{tabular}

Примітка: чисельник - твердосплавні Пуасонье, оброблені на заточном колі, знаменник те ж, поліровані

Дослідженнями встановлено, що втрата вологи у граніту відбувається значно швидше, ніж у пісковика, що можна пояснити його структурою, тобто великою наявністю великих тріщин. При приміщенні його в рідину велика кількість вологи проникає в зразок, зменшуючи його властивості міцності. У пісковика, що має більш дрібні зерна, а, отже, і менша кількість часу, капілярів і тріщин, проникнення рідини утруднено, що і впливає на зміну його міцності властивостей. Добавки розчинника ДБ в воду сприяє активному проникненню іiі в гірську породу i викликає помітне зниження міцності властивостей. Зміна шорсткості твердосплавних пуансонів не викликає істотної зміни характеристик міцності властивостей гірських порід.

Таким чином встановлено, що зменшуючи в'язкість промивної рідини, можна змінити властивості міцності гірських порід. Незначні добавки змочувача ДБ викликають зниження (до 2 разів) межі міцності у граніту, що пов'язано 3 ефектом Ребіндера. Зміна шорсткості пуансонів не дає істотної зміни характеристик міцності властивостей досліджуваних порід.

Подальше дослідження впливу добавок ПАР і шорсткості твердосплавних пластин на ефективність процесу руйнування при різанні проводилося на буровому стенді.

Режими обертального буріння при введенні в промивну рідину розчинника ДБ.

Проведеними дослідженнями встановлено, що зменшення поверхневого натягу води шляхом додавання в неї розчинника ДБ викликає зменшення міцності властивостей гірських порід. Поряд 3 цим вода, оброблена ДБ, має підвищену проникаючу здатність i властивість зменшувати коефіцієнт тертя на границі твердий сплав - порода. Ця обставина має впливати на зменшення величини ядра ущільнення.

3 метою перевірки цих положень і відпрацювання режимів буріння при використанні води з розчинником ДБ проведено експериментальне буріння по гранітам 3 коефіцієнтом фортеці породоруйнівним інструментом Б1741А зі звичайною і полірованої алмазною пастою передній гранями. Винесення продуктів руйнування здійснювалося водою 3 додаванням $0,05 \%$ розчинника ДБ. Буріння велося на верстаті ЗИФ-300 при зусиллях подачі, що не перевищують 15 кН. В процесі буріння проводився запис потужності, споживаної верстатом, і вимірялася швидкість буріння. Буріння велося протягом $30 \mathrm{c}$, кожен раз новим або заточеним інструментом. Перша серія дослідів велася при частоті обертання інструменту 144 хв, що відповідає області обертання, близької до оптимальної.

Полірування передній грані дозволила збільшити швидкість буріння на 14 - $16 \%$, а добавки ДБ при неполірований різці збільшують швидкість на $20 \%$ в порівнянні з бурінням звичайним інструментом і 3 промиванням водою. 
Зменшення шорсткості передній грані і додавання в воду ДБ дозволили збільшити швидкість буріння граніту на $40-50 \%$. Заміри ширини площадки затуплення, віднесеної до одиниці довжини разбуреного шпуру, показали, що добавки ДБ зменшують інтенсивність затуплення на $25 \%$, а полірування передній грані і додавання ДБ - до $40 \%$ в порівнянні зі звичайним бурінням.

Дослідження показали, що зі збільшенням зусилля подачі потужність, споживана двигуном зростає по лінійної залежності.

Об'ємна робота руйнування зменшується зі збільшенням зусилля подачі і при досягненні 10 - 15 кН залишається майже незмінною.

Дослідження залежностей параметрів буріння від частоти обертання інструменту показали, що при застосуванні води для виносу продуктів руйнування, оптимальна частота обертання відповідає $150 \mathrm{xв}^{-1}$. При використанні добавки ДБ і при поліровці передній грані оптимальна частота обертання становить $180 \mathrm{xв}^{-1}$.

Оцінюючи отримані результати буріння 3 водою і водою добавками ДБ можна вважати, що зменшення поверхневого натягу промивної рідини дозволяе вести буріння на форсованих режимах, тобто з великими швидкостями різання.

Підвищення ефективності буріння можна пояснити, виходячи з процесу руйнування гірських порід різанням. Якщо різання здійснюється 3 утворенням ядра ущільнення, величина останнього може бути зменшена за рахунок сил тертя на кордоні різець-порода. Аналогічний ефект викликає і додавання ДБ в промивну рідину, яка проникає в предрізцовий простір, зменшуючи ядро ущільнення, покращуючи умови різання і охолодження твердого слава.

Поряд з цими факторами підвищення ефективності буріння необхідно відзначити і разупрочнення гірських порід за рахунок ефекту Ребіндера (зниження поверхневої енергії руйнування).

Вплив ПАР на гірську породу викликає іï разупрочнення і покращує умови ії руйнування.

Встановлено, що застосування добавок ДБ збільшує швидкість обертального буріння на $25-30 \%$ і глибину проходки до його затуплення на $20-25 \%$. Остання обставина сприяє зменшенню витрат на спускопідйомні операції, що набуває першочергового значення при бурінні глибоких свердловин.

Результати дослідно-промислових випробувань показали, що використання добавок пі- ноутворювача ДБ в промивної рідини при обертальному бурінні економічно доцільно.

Також проводяться роботи по розробці теоретичних моделей руйнування [8]. Так за допомогою математичної моделі описана система гасіння поперечних коливань бурового става, що включає накладні ковзаючі напівмуфти, які притискаються до ставу поперечними силами, при цьому амплітуда поперечних коливань в процесі поглиблення свердловини і зміщення накладок до верхнього кінця бурового ставу змінюється від 1,4 мм до 7,4 мм, що менше зазору між поверхнею ставу і стінкою свердловини, чим виключається режим резонансного віброударної сили і флатер бурового інструменту; Шляхом фізичного моделювання визначаються параметри обертання верстата шарошечного буріння: частота обертів - 2 Гц при зусиллі подачі $-572,5$ H і амплітуда поперечних коливань бурового ставу $-4,9$ мм.

\section{Висновки}

Встановлено залежність появи флатера бурового інструменту внаслідок збігу частоти його обертання 3 власною частотою поперечних коливань бурового ставу, на буровому ставі, який складається 3 3-х восьмиметрових штанг, флатер з'являється на I частоті обертів $30 \mathrm{xB}^{-1}$, a на буровому ставі, що складається 32 -х восьмиметрових штанг - на частоті І оборотів $113 \mathrm{xB}^{-1}$.

Встановлено шляхом математичного моделювання нелінійні безрозмірні залежності; частот i амплітуд поперечних власних коливань бурового ставу як від параметрів обертання ставу, так і від зовнішніх факторів. Спираючись на теорію подібності та аналізу розмірностей це дозволяє вивчити вплив параметрів не окремо, а в комплексі, що зменшує обсяг досліджень до 2-х раз.

У теоретичному аналізі ефективності амортизаторів згинальних коливань - АІК, встановлено, що вони дозволяють значно (в 6 разів) зменшити поперечні коливання бурового става до 26 мм, однак не виключають появу флатера бурового інструменту, тому обгрунтован вибір більш ефективної системи виброгашення 3 накладними легкими напівмуфтами (НСП).

Також розробляються системи гасіння поперечних коливань НСП, ефективність, якої перевіряється розрахунками і моделюється за допомогою SolidWorks, що виключає флатер бурового інструменту. Проводяться розробки моделей верстатів шарошечного буріння, які 
дозволяють виробнику верстатів вибирати раціональні параметри систем гасіння поперечних коливань бурових ставів, проект верстата використаний для розробки робочої документації діючої моделі.

Таким чином в Україні ведуться роботи і $є$ всі можливості для проведення робіт по зниженню енергоємності та підвищення продуктивності при бурінні свердловин, також виготовлення установок для глибокого буріння на машинобудівних заводах країни і оснащувати їх власними комплектуючими виробами.

Наукове і інженерне забезпечення виконується Національним технічним університетом «Дніпровська політехніка», також роботи проводяться в Українському державному науководослідному геологорозвідувальному інституті (УкрГНІГРІ), Івано-Франківському державному університеті нафти і газу (ІФГУНГ). Проектноконструкторські роботи виконуються в ДКБ "Південне", Полтавському відділенні УкрГНІГPI, ПКТИ АТ "Дніпроважмаш", КБ АТ "Сумський машинобудівний завод".

\section{Бібліографічний список}

1. Пащенко О. А., Ганкевич В. Ф. Технологічні резерви зменшення енергоємності руйнування в умовах дії гідростатичного тиску. 3багачення корисних копалин. 2016. Вип. 64(105). C. $36-42$.

2. Ганкевич В. Ф., Ливак О. В. Исследование процессов разрушения горных пород с использованием температурного фактора. Збагачення корисних копалин. 2017. Вип. 68(109). C. $46-55$.

3. Ганкевич В. Ф., Ливак В. И. О температура нагрева поверхности горной породы при движении по ней плоского штампа. Зб. наук. праџьь ІГТМ НАН України. 2018. № 135. C. 54-62.

4. Ганкевич В. Ф., Курнат Н. Л., Пащенко А. А.. Киба В. Я. О влиянии лазерного излучения на надежность режущего инструмента горных машин. Міжвідомчий збірник наукових працьь IГТМ. 2018. Вип. 137. С. 10-16.

5. Патент на корисну модель «Термомеханічний породоруйнівний інструмент» № 131521 від 25.01.2019. - Бюл. № 2, 2019. Ганкевич В. Ф., Вахалін Ю. М., Лівак О. В.

6. Ганкевич В. Ф., Курнат Н. Л., Ливак О. В. Математическое обоснование процессов разрушения горных пород. Збагачення корисних копалин. 2018. Вип. 70(111). С. 29-34.
7. Антончик В. С., Назаров А. Е., Ганкевич В. Ф., Ливак О. В. Повышение К.П.Д. пневмоударных машин. Збагачення корисних копалин. 2019. Вип. 73(114). С. 67-74.

8. Ганкевич В.Ф., Пащенко О.А., Киба В. Я. Вплив вібрацій на буровий інструмент. Всеукраӥнський науково-технічний журнал «Biбрації в техніиі та технологіях». 2015. Вип. 4(8). С. 132-135.

9. Москалев А. Н., Ганкевич В. Ф., Бабец В. В. Породоразрушающие инструменты для вращательного бурения по крепким породам. Уголь Украины. Киев «Техніка». 1997. № 4. C. 32-33.

10. Сірик В. Ф., Титов О. О., Ганкевич В. Ф., Луцик О. С. Свердловинні амортизатори як засіб підвищення продуктивності буріння твердих порід. Наук. вісник НТУ. 2009. № 1. C. $10-13$.

11. Громадський В. А. Обгрунтування раціональних експлуатаційних параметрів обертальних бурових верстатів шарошкового буріння. Автореферат на здобуття наукового ступеня канд. техн. наук. Кривий Ріг. 2016.

\section{References}

1. Pashchenko, O. A., \& Gankevich, V. F. (2016). Technological reserves for reducing the energy consumption of destruction under conditions of hydrostatic pressure. Enrichment of minerals, 64(105), 36-42

2. Gankevich, V. F., \& Livak, O. V. (2017). Investigation of rock destruction processes using the temperature factor. Enrichment of minerals, 68(109), 46-55

3. Gankevich, V. F., \& Livak, V. I. (2018). About the heating temperature of the rock surface when moving a flat stamp on it. Collection of scientific works of IGTM of NAS of Ukraine, (135), 54-62

4. Gankevich, V. F., Kurnat, N. L., Pashchenko, O. A., \& Kiba, V. Y. (2018). On the influence of laser radiation on the reliability of the cutting tool of mining machines. Interdepartmental collection of scientific works of IGTM, 137, 10-16

5. Gankevich, V. F., Vakhalin, Y. M., \& Livak, O. V. (2019). UA Patent for a utility model No. 131521. "Thermomechanical rock-destroying tool". Kyiv: Derzhavne patentne vidomstvo Ukrainy

6. Gankevich, V. F., Kurnat, N. L., \& Livak, O. V. (2018). Mathematical substantiation of rock destruction processes. Enrichment of minerals, 70(111), 29-34 
7. Antonchik, V. S., Nazarov, A. E., Gankevich, V. F., \& Livak, O. V. (2019). Increasing KPD pneumatic shock machines. Enrichment of minerals, 73(114), 67-74

8. Hankevich, V. F., Pashchenko, O. A., \& Kiba, V. Y. (2015). Influence of vibrations on drilling tools. All Ukrainian scientific and technical journal "Vibrations in Engineering and Technolo$g y^{\prime \prime}, 4(8), 132-135$

9. Moskalev, A. N., Gankevich, V. F., \& Babets, V. V. (1997). Rock-breaking tools for rotary drilling on strong rocks. Coal of Ukraine. Kiev "Technology", (4), 32-33

10. Sirik, V. F., Titov, O. O., Gankevich, V. F., \& Lutsyk O. S. (2009). Downhole shock absorbers as a means of increasing the productivity of drilling hard rocks. Scientific Bulletin of NTU, (1), $10-13$

11. Hromadsky, V. A. (2016). Substantiation of rational operational parameters of rotary cone drilling rigs. Abstract for the degree of Candidate of Technical Sciences. Krivoy Rog

Назаров Олександр Євгенійович, старший науковий співробітник, Інститут геотехнічної механіки НАН України (Дніпро, Україна). E-mail: office.igtm@nas.gov.ua

Ганкевич Валентин Феодосійович, доцент, кандидат технічних наук, доцент кафедри гірничих машин та інжинірингу, Національний технічний університет «Дніпровська політехніка» (Дніпро, Україна). ORCID ID: 0000-0002-8535-6318. E-mail: hankevych.v.f@nmu.one

Пащенко Олександр Анатолійович, доцент, кандидат технічних наук, доцент кафедри нафтогазової інженерії та буріння, Національний технічний університет «Дніпровська політехніка» (Дніпpo, Україна). ORCID ID: 0000-0003-3296-996X. E-mail: Pashchenko.O.A@nmu.one

Кіба В'ячеслав Якович, старший викладач кафедри будівельної, теоретичної та прикладної механіки, Національний технічний університет «Дніпровська політехніка» (Дніпро, Україна). E-mail: Kiba.v.ya@nmu.one

\section{ШЛЯХИ ЗМЕНШЕННЯ ЕНЕРГОСМНОСТІ І ПДВИЩЕННЯ ПРОДУКТИВНОСТІ ПРИ БУРІННІ СВЕРДЛОВИН}

Мета. В роботі розглянуто напрями та розробки що направлені на підвищення продуктивності процесу буріння, зниження енерговитрат і підвищення надійності обладнання, в першу чергу інструменту. Так розглянуто застосування гідравлічних бурових установок, що дозволяють: знизити в $1,5 \ldots 1,8$ рази масу бурової установки, скоротити в 1,5 рази час спускопідімальні операції; забезпечити підвищення швидкості буріння в $1,3 \ldots 2$ рази, знизити час на нарощування бурильних труб в 2,5 рази, скоротити час на монтаж і демонтаж установки в 2...5 разів. Дослідження процесу руйнування гірської породи показали, що вплив ПАР на гірську породу викликає іiї разупрочнення і покращує умови іiі руйнування. Застосування добавок ДБ збільшує швидкість обертального буріння на 25 - 30 \% і глибину проходки до його затуплення на $20-25 \%$. Результати дослідно-промислових випробувань показали, що використання добавок піноутворювача ДБ в промивної рідини при обертальному бурінні економічно доцільно.

Методика. Роботи по розробці теоретичних моделей руйнування [8] шляхом математичного моделювання дозволяють розрахувати нелінійні безрозмірні залежності; частот і амплітуд поперечних власних коливань бурового ставу як від параметрів обертання ставу, так і від зовнішніх факторів. Спираючись на теорію подібності та аналізу розмірностей це дозволяє вивчити вплив параметрів не окремо, а в комплексі, що зменшує обсяг досліджень до 2-х раз.

Результати. Системи гасіння поперечних коливань НСП, ефективність, якої перевіряється розрахунками і моделюється за допомогою SolidWorks, що виключає флатер бурового інструменту. Проводяться розробки моделей верстатів шарошкового буріння, які дозволяють виробнику верстатів вибирати раціональні параметри систем гасіння поперечних коливань бурових ставів, проект верстата використаний для розробки робочої документації діючої моделі.

Наукова новизна. Встановлено залежність появи флатера бурового інструменту внаслідок збігу частоти його обертання з власною частотою поперечних коливань бурового ставу, на буровому ставі, який складається 3 3-х восьмиметрових штанг, флатер з'являється на I частоті обертів $30 \mathrm{xв}^{-1}$, а на буровому ставі, що складається з 2-х восьмиметрових штанг - на частоті І оборотів $113 \mathrm{xB}^{-1}$.

Встановлено шляхом математичного моделювання нелінійні безрозмірні залежності; частот і амплітуд поперечних власних коливань бурового ставу як від параметрів обертання ставу, так і від зов- 
нішніх факторів. Спираючись на теорію подібності та аналізу розмірностей це дозволяє вивчити вплив параметрів не окремо, а в комплексі, що зменшує обсяг досліджень до 2-х раз.

У теоретичному аналізі ефективності амортизаторів згинальних коливань - АІК, встановлено, що вони дозволяють значно (в 6 разів) зменшити поперечні коливання бурового става до 26 мм, однак не виключають появу флатера бурового інструменту, тому обгрунтован вибір більш ефективної системи виброгашення з накладними легкими напівмуфтами (НСП).

Практична цінність. Розробка систем гасіння поперечних коливань НСП, ефективність, яких перевіряється розрахунками і моделюється за допомогою SolidWorks, що виключає флатер бурового інструменту. Проведення розробки моделей верстатів шарошечного буріння, які дозволяють виробнику верстатів вибирати раціональні параметри систем гасіння поперечних коливань бурових ставів, проект верстата використано для розробки робочої документації діючої моделі.

Проведення робот по зниженню енергоємності та підвищення продуктивності при бурінні свердловин, також виготовлення установок для глибокого буріння на машинобудівних заводах країни $\mathrm{i}$ оснащувати їх власними комплектуючими виробами.

Наукове і інженерне забезпечення виконується Національним технічним університетом «Дніпровська політехніка», також роботи проводяться в Українському державному науково-дослідному геологорозвідувальному інституті (УкрГНІГРІ), Івано-Франківському державному університеті нафти і газу (ІФГУНГ). Проектно-конструкторські роботи виконуються в ДКБ "Південне", Полтавському відділенні УкрГНІГРІ, ПКТИ АТ "Дніпроважмаш", КБ АТ "Сумський машинобудівний завод".

Ключові слова: енерговитрати, енергоефективність, руйнування, коливання, флатер.

Oleksandr Nazarov, Senior Research Fellow, Institute of Geotechnical Mechanics of National Academy of Sciences of Ukraine (Dnipro, Ukraine). Email: office.igtm@nas.gov.ua

Valentyn Gankevych, Associate Professor, Candidate of Technical Sciences, Associate Professor of the Department of Mining Machines and Engineering, National Technical University "Dnipro Polytechnic" (Dnipro, Ukraine). ORCID ID: 0000-0002-8535-6318. Email: hankevych.v.f@nmu.one

Oleksandr Pashchenko, Associate Professor, Candidate of Technical Sciences, Associate Professor of the Department of Oil and Gas Engineering and Drilling, Dnipro Polytechnic National Technical University (Dnipro, Ukraine). ORCID ID: 0000-0003-3296-996X. Email: Pashchenko.O.A@nmu.one

Vyacheslav Kiba, Senior Lecturer, Department of Structural, Theoretical and Applied Mechanics, Dnipro Polytechnic National Technical University (Dnipro, Ukraine). Email: Kiba.v.ya@nmu.one

\section{WAYS TO REDUCE ENERGY CONSUMPTION AND INCREASE PRODUCTIVITY WHEN DRILLING WELLS}

Purpose. The paper considers areas and developments aimed at improving the productivity of the drilling process, reducing energy consumption and improving the reliability of equipment, especially tools. Thus, the use of hydraulic drilling rigs is considered, which allows: to reduce by $1.5 \ldots 1.8$ times the weight of the drilling rig, to reduce by 1.5 times the time of lifting operations; to provide increase of speed of drilling in 1.3... 2 times, to reduce time for building of drill pipes in 2.5 times, to reduce time for installation and dismantle of installation in 2...5 times. Studies of the process of rock destruction have shown that the effect of surfactants on the rock causes its softening and improves the conditions of its destruction. The use of DB additives increases the speed of rotary drilling by $25-30 \%$ and the depth of penetration to its blunting by $20-25 \%$. The results of experimental and industrial tests have shown that the use of additives foaming agent DB in the flushing fluid during rotary drilling is economically feasible.

Methods. Work on the development of theoretical models of destruction [8] by mathematical modeling allows to calculate nonlinear dimensionless dependences; frequencies and amplitudes of transverse natural oscillations of the drilling pond both from the parameters of the pond rotation and from external factors. Based on the theory of similarity and dimensional analysis, it allows to study the influence of parameters not separately, but in a complex, which reduces the amount of research to 2 times.

Results. NSP transverse vibration damping systems, the efficiency of which is verified by calculations and simulated using SolidWorks, which eliminates the flutter of the drilling tool. Models of cone drilling machines are being developed, which allow the machine tool manufacturer to choose rational parameters of systems for damping transverse oscillations of drilling rigs, the machine tool design is used to develop work- 
ing documentation of the current model.

Originality. The dependence of the occurrence of the drilling tool flutter due to the coincidence of its speed with the natural frequency of transverse oscillations of the drilling rig, on the drilling rig, which consists of 3 eight-meter rods, the flutter appears at I speed $30 \mathrm{~min}^{-1}$, and on the drilling rig, consisting of 2 eight-meter rods - at a frequency of I rpm $113 \mathrm{~min}^{-1}$.

Nonlinear dimensionless dependences are established by mathematical modeling; frequencies and amplitudes of transverse natural oscillations of the drilling pond both from the parameters of the pond rotation and from external factors. Based on the theory of similarity and dimensional analysis, it allows to study the influence of parameters not separately, but in a complex, which reduces the amount of research to 2 times.

In the theoretical analysis of the effectiveness of bending shock absorbers - AIC, it was found that they can significantly ( 6 times) reduce the transverse oscillations of the drilling rig to $26 \mathrm{~mm}$, but do not exclude the occurrence of drilling tool flutter, so it is justified to choose a more efficient vibration damping system. NSP).

Practical implications. Development of NSP transverse vibration damping systems, the efficiency of which is verified by calculations and modeled using SolidWorks, which eliminates the flutter of the drilling tool. Development of models of cone drilling machines, which allow the machine tool manufacturer to choose rational parameters of systems for damping transverse oscillations of drilling rigs, the design of the machine is used to develop working documentation of the current model.

Carrying out of works on decrease in energy consumption and increase of productivity at drilling of wells, and also manufacturing of installations for deep drilling at machine-building plants of the country and to equip them with own accessories.

Scientific and engineering support is provided by the National Technical University "Dnipro Polytechnic", and work is carried out at the Ukrainian State Research Geological Exploration Institute (UkrGNIGRI), Ivano-Frankivsk State University of Oil and Gas (IFGUNG). Design works are performed in DKB "Pivdenne", Poltava branch of UkrGNIGRI, PKTI JSC "Dniprovazhmash", KB JSC "Sumy Machine-Building Plant".

Key words: energy consumption, energy efficiency, destruction, oscillations, flutter.

Назаров Александр Евгеньевич, старший научный сотрудник, Институт геотехнической механики НАН Украины (Днепр, Украина). E-mail: office.igtm@nas.gov.ua

Ганкевич Валентин Феодосьевич, доцент, кандидат технических наук, доцент кафедры горных машин и инжиниринга, Национальный технический университет «Днепровская политехника» (Днепр, Украина). ORCID ID: 0000-0002-8535-6318. E-mail: hankevych.v.f@nmu.one

Пащенко Александр Анатольевич, доцент, кандидат технических наук, доцент кафедры нефтегазовой инженерии и бурения, Национальный технический университет «Днепровская политехника» (Днепр, Украина). ORCID ID: 0000-0003-3296-996X. E-mail: Pashchenko.O.A@nmu.one

Киба Вячеслав Яковлевич, старший преподаватель кафедры строительной, теоретической и прикладной механики, Национальный технический университет «Днепровская политехника» (Днепр, Украина). E-mail: Kiba.v.ya@nmu.one

\section{ПУТИ УМЕНЫШЕНИЯ ЭНЕРГОЕМКОСТИ И ПОВЫШЕНИЯ ПРОИЗВОДИТЕЛЬНОСТИ ПРИ БУРЕНИИ СКВАЖИН}

Цель. В работе рассмотрены направления и разработки направленных на повышение производительности бурения, снижение энергозатрат и повышение надежности оборудования, в первую очередь инструмента. Так рассмотрено применение гидравлических буровых установок, позволяющих: снизить в $1,5 \ldots 1,8$ раза массу буровой установки, сократить в 1,5 раза время спускоподъемные операции; обеспечить повышение скорости бурения в $1,3 \ldots 2$ раза, снизить время на наращивание бурильных труб в 2,5 раза, сократить время на монтаж и демонтаж установки в $2 \ldots 5$ раз. Исследование процесса разрушения горной породы показали, что влияние ПАВ на горную породу вызывает ее разупрочнения и улучшает условия ее разрушения. Применение добавок ДБ увеличивает скорость вращательного бурения на 25 - 30 \% и глубину проходки до его затупления на 20 - 25 \%. Результаты опытно-промышленных испытаний показали, что использование добавок пенообразователя ДБ в промывочной жидкости при вращательном бурении экономически целесообразно. 
Методика. Работы по разработке теоретических моделей разрушения [8] путем математического моделирования позволяют рассчитать нелинейные безразмерные зависимости; частот и амплитуд поперечных собственных колебаний бурового става как от параметров вращения пруда, так и от внешних факторов. Опираясь на теорию подобия и анализа размерностей это позволяет изучить влияние параметров не отдельно, а в комплексе, уменьшает объем исследований до 2-х раз.

Результаты. Системы гашения поперечных колебаний НСП, эффективность, которой проверяется расчетами и моделируется с помощью SolidWorks, что исключает флаттер бурового инструмента. Проводятся разработки моделей станков шарошечного бурения, которые позволяют производителю станков выбирать рациональные параметры систем гашения поперечных колебаний буровых прудов, проект станка использован для разработки рабочей документации действующей модели.

Научная новизна. Установлена зависимость появления флаттера бурового инструмента вследствие стечения частоты его вращения с собственной частотой поперечных колебаний бурового става, на буровом ставе, который состоит из 3-х восьмиметровых штанг, флаттер появляется на I частоте оборотов 30 мин $^{-1}$, а на буровом ставе, состоящий из 2-х восьмиметровых штанг - на частоте І оборотов 113 мин $^{-1}$.

Установлено путем математического моделирования нелинейных безразмерные зависимости; частот и амплитуд поперечных собственных колебаний бурового става как от параметров вращения пруда, так и от внешних факторов. Опираясь на теорию подобия и анализа размерностей это позволяет изучить влияние параметров не отдельно, а в комплексе, уменьшает объем исследований до 2-х раз.

В теоретическом анализе эффективности амортизаторов изгибных колебаний - АИК, установлено, что они позволяют значительно (в 6 раз) уменьшить поперечные колебания бурового става до 26 мм, однако не исключают появление флаттера бурового инструмента, поэтому обоснованный выбор более эффективной системы виброгашення с накладными легкими полумуфтами ( НСП).

Практическая ценность. Разработка систем гашения поперечных колебаний НСП, эффективность, которых проверяется расчетами и моделируется с помощью SolidWorks, что исключает флаттер бурового инструмента. Проведение разработки моделей станков шарошечного бурения, которые позволяют производителю станков выбирать рациональные параметры систем гашения поперечных колебаний буровых прудов, проект станка использованы для разработки рабочей документации действующей модели.

Проведение работ по снижению энергоемкости и повышение производительности при бурении скважин, также изготовление установок для глубокого бурения на машиностроительных заводах страны и оснащать их собственными комплектующими изделиями.

Научное и инженерное обеспечение выполняется Национальным техническим университетом «Днепровская политехника», также работы проводятся в Украинском государственном научноисследовательском геологоразведочном институте (УкрГНИГРИ), Ивано-Франковском государственном университете нефти и газа (ИФГУНГ). Проектные работы выполняются в ГКБ "Южное", Полтавском отделении УкрГНИГРИ, ПКТИ АО "Днепротяжмаш", КБ АО "Сумской машиностроительный завод".

Ключевые слова: энергозатраты, энергоэффективность, разрушения, колебания, флаттер. 